\title{
STUDIES ON THE SECRETORY POTENTIAL OF ACINAL CELL OF DOG'S SUBMAXILLARY GLAND AND THE IONIC DEPENDENCY OF IT
}

\author{
Hisato YoshimuRA AND Yusuke IMAI \\ Department of Physiology, Kyoto Prefectural University \\ of Medicine
}

Electrophysiological studies by LUNDBURG ${ }^{6-10}$ ) have thrown light on the study of the salivary gland of which the secretory mechanism is not known. $\mathrm{He}$ found that the membrane potentials of acinal cells of cat's submaxillary gland and sublingual gland are hyperpolarized by stimulation of the chorda tympani, and called this hyperpolarized potential the secretory potential. The origin of these potential changes is not clarified in detail. LUNDBURG has discussed the various possibilities and concluded that the hyperpolarization of the intracellular potential is due to an active transport of chloride ion from the extracellular fluid into the cell.

It has been previously reported by the present authors ${ }^{4,5}$ that the intracellular resting potential of the acinal cell of dog's submaxillary gland was $-42 \mathrm{mV}$ on an average of 150 measurements, and the potential is hyperpolarized by stimulation of the chorda nerve to $-57 \mathrm{mV}$ on an average. The site of this potential generation was confirmed to be located in an acinal cell of the gland with the Turnble blue method. In an attempt to examine the hypothesis of LUNDBURG, a perfusion experiment on dog's submaxillary gland was performed, and the intracellular potential was measured with the microelectrode method. The ionic balance study of the nonperfused gland and the analysis of ionic concentrations of the gland tissue were also carried out.

\section{METHOD}

The dogs were anesthetized with sodium thiopental ( $30-50 \mathrm{mg} / \mathrm{Kg}$ intravenously). The submaxillary gland was dissected, leaving the nerves, duct, and blood vessels connected to the head of the animal. A cannule was inserted into the duct to collect the saliva flowing out of it.

Perfusion. All branches from the carotid artery and juglar vein were ligated except those leading to the submaxillary gland. One of the carotid branches, usually the lingular artery, was connected to a cannule of the perfusion apparatus, which had been

Received for publication August 26, 1966

吉村寿人, 今井雄介 
devised by INOUE ${ }^{3)}$, and reported elesewhere 4 ,15). A hydrostatic pressure of $120 \mathrm{cmH}_{2} \mathrm{O}$ was used to flow the perfusate which was warmed by passing it through a $38^{\circ} \mathrm{C}$-bath. The perfusate was circulated through the submaxillary gland after clamping the carotid

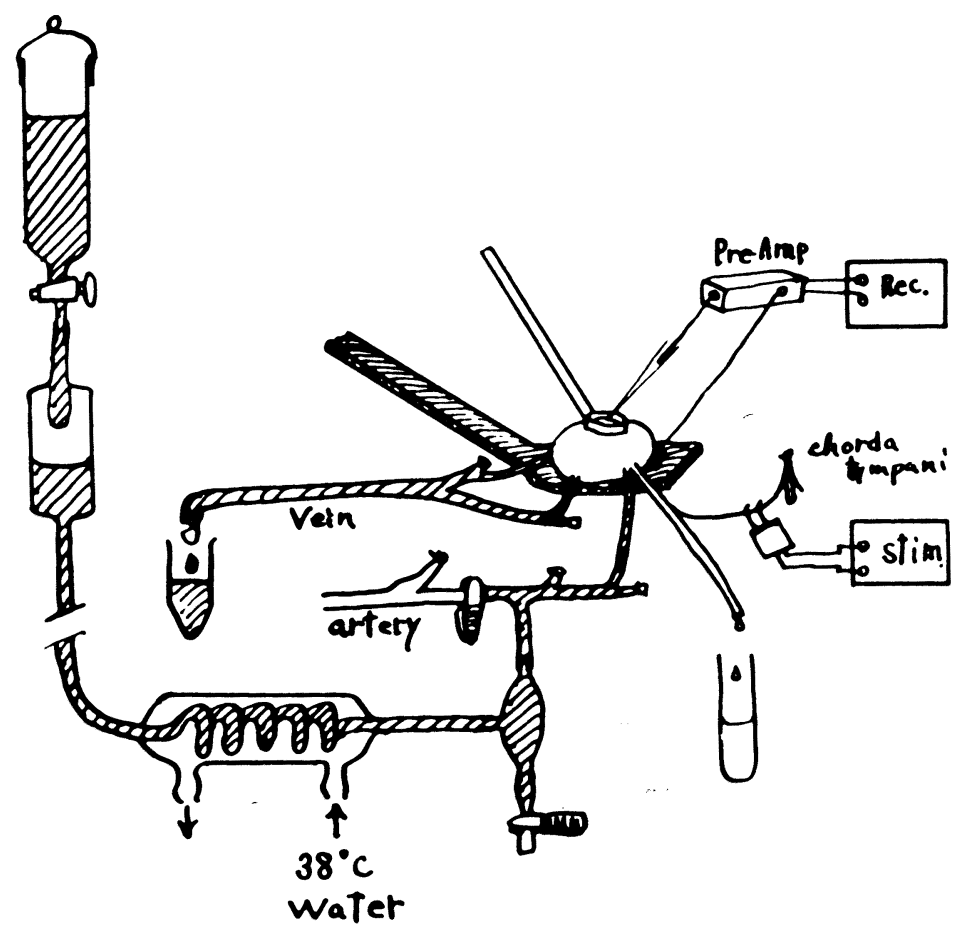

FIG. 1. Schematic representation of perfusion experiment with microglass-electrode.

TABLE 1. Composition of the perfusate.

Normal-Ringer
$\mathrm{NaCl}$
$\mathrm{KCl}$
$\mathrm{NaHCO}_{3}$
$\mathrm{CaCl}_{2}$
$\mathrm{MgSO}_{4}$
$\mathrm{Li}-\mathrm{Ringer}$
$\mathrm{LiCl}$
$\mathrm{KCl}$
$\mathrm{CaCl}_{2}$
$\mathrm{MgSO}_{4}$

$\mathrm{K}$-isotonic Solution $\mathrm{KCl}$

$140.0(\mathrm{mM})$
4.0
10.0
2.0
1.3
$140.0(\mathrm{mM})$
4.0
2.0
1.3

$150.0(\mathrm{mM})$

$\mathrm{NO}_{3}-\mathrm{Ringer}$
$\mathrm{NaNO}_{3}$
$\mathrm{KNO}_{3}$
$\mathrm{NaHCO}_{3}$
$\mathrm{Ca}\left(\mathrm{NO}_{3}\right)_{2}$
$\mathrm{MgSO}_{4}$
$\mathrm{SO}_{4}-\mathrm{Ringer}$
$\mathrm{Na}_{2} \mathrm{SO}_{4}$
$\mathrm{~K}_{2} \mathrm{SO}_{4}$
$\mathrm{NaHCO}_{3}$
$\mathrm{MgSO}_{4}$
$\mathrm{~K}-\mathrm{free}_{\mathrm{Ringer}}$
$\mathrm{NaCl}$
$\mathrm{NaHCO}_{3}$
$\mathrm{CaCl}_{2}$
$\mathrm{MgSO}_{4}$

$140.0(\mathrm{mM})$

4. 0

10.0

2.0

1.3

$90.0(\mathrm{mM})$

2.0

10.0

2. 0

$144.0(\mathrm{~m} \mathrm{M})$

10.0

2.0

1.3

Each solutions are added $25 \mathrm{~g}$ of PVP per litter. 
artery (FIG. 1). The perfusate was composed of an isotonic saline solution as indicated in TABLE $1,2.5 \%$ of polyvinyle pyrrolidone (PVP) which maintained the colloid-osmotic pressure, and red blood cells which were suspended in $35 \mathrm{Vol} \%$ to supply enough oxygen to the gland.

Micro-glass-electrode. Conventional glass capillary microelectrodes as described by LING and GERARD were used for recording the intracellular potential. They were filled with $3 \mathrm{M}-\mathrm{KCl}$ and had a resistance of from 10 to $30 \mathrm{M} \Omega$. Each microelectrode tip was checked with a microscope $(\times 500)$ before use. The gland was placed on a plastic spoon which had been covered with a reference electrode $(\mathrm{Ag}-\mathrm{AgCl})$, and was fixed by pressing a plastic ring on the surface of the gland (see FIG. 1). For recording the intracellular potential, a cathode follower type preamplifier (Nihon-Koden MZ-3A), dc-main amplifier (Nihon-Koden $\mathrm{ADH}-2$ ) and a pen-recorder (Nihon-Koden W-1) were used. The secretion of saliva was provoked by stimulating the chorda tympani with an electric stimulator (Nihon-Koden MSE-3) which generated a tetanic current (usually 2V, $20 \mathrm{cps}$, pulse duration $5 \mathrm{msec}$ ).

Ionic balance study. Similarly to BURGEN's experiment ${ }^{1)}$, the venous blood from the gland was collected every $30-60 \mathrm{sec}$. separately during the resting, secreting and restoring state. The ionic concentrations of the plasma and the flowing rate of blood were measured. The ionic concentration and flowing rate of saliva were also measured. The ionic balances of the gland were examined, respectively during the resting, secreting and restoring state, and the ionic balance in the gland tissue was calculated from the measurements of the flowing rate and the concentration of the saliva and blood. Sodium and potassium were measured with the flame-photometer (Lange), chloride by the titlating method of Sharles and Sharles and inorganic phosphate by the Fiske-Subbaraw method.

Ionic concentration of gland tissue. With the dog nephrectomized ${ }^{11)}$, the submaxillary glands on both sides were removed one by one at the resting state and then the secreting state, 30 minutes after an intravenous injection of inulin $(0.2 \mathrm{~g} / \mathrm{Kg}$ of body weight). The secreting state was maintained for five minutes by stimulating the chorda tympani $(2 \mathrm{~V}, 20 \mathrm{cps})$. After obtaining the wet weight, dry weight of the excised gland, inulin concentrations of the homogenate and plasma were measured to calculate the inulin space of the gland11,12,13). The ionic concentrations in the plasma and gland homogenate were also measured to calculate the ionic content in gland cell.

\section{RESULTS}

Intracellular potential of the acinal cell of the perfused gland. When the submaxillary gland was perfused with the perfusate of normal ionic content (arterial blood or TABLE 1, normal Ringer), the intracellular potential of the acinal cell was $-40 \pm 8 \mathrm{mV}$ at the resting state, on an average of 200 measurements, and was hyperpolarized to $-54.5 \pm 11 \mathrm{mV}$ on an average at the secreting state provoked by electric stimulation of the chorda tympani. The secreting rate of saliva was $0.02-0.1 \mathrm{ml} / \mathrm{min} / \mathrm{g}$. gland. The latency of this hyperpolarization was $0.4 \mathrm{sec}$. and the rate of its rise was $13-25 \mathrm{mV} / \mathrm{sec}$. The hyperpolarization reached its maximum after 1-2 secs., and then it was maintained at an almost constant level during stimulation. Thus this characteristic feature of the hyperpolarization seems to correspond to the first type of secretory potential described by LUNDBERG with cats' submaxillary gland (see FIG. 2 left side). 

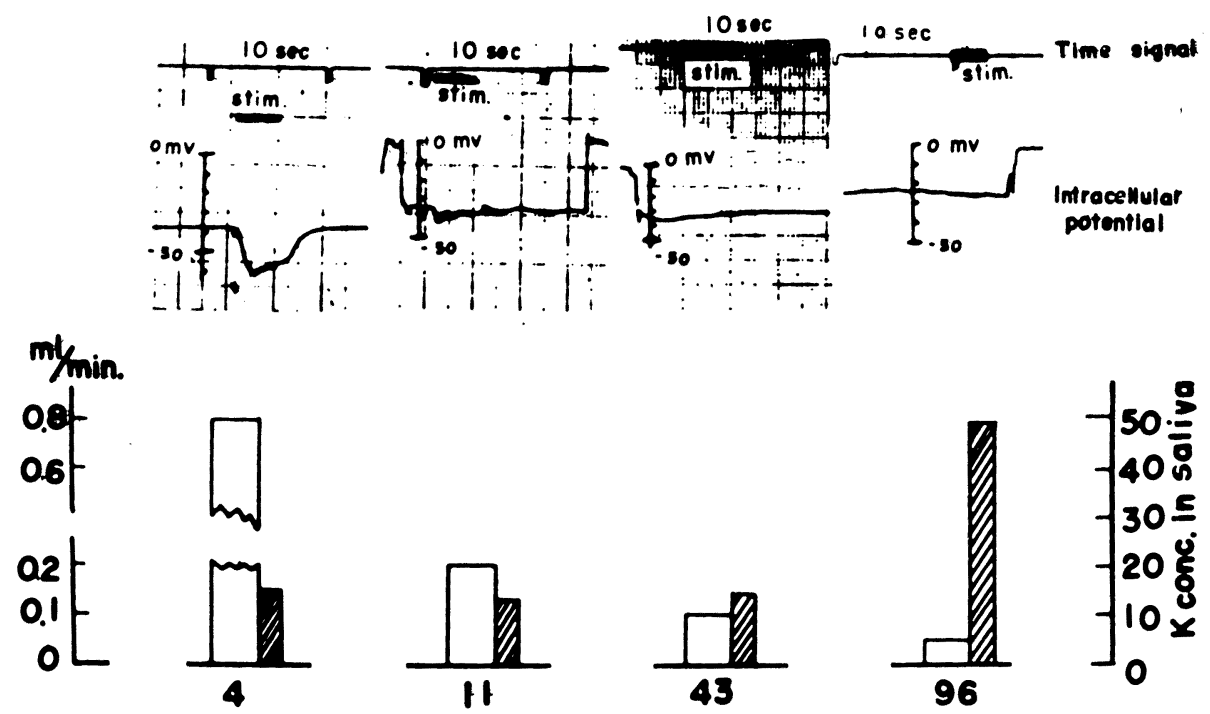

$[\mathrm{K}]_{0}$

FIG. 2. Effect of increased $\mathrm{K}^{+}$concentration in the perfusate on the intracellular potential, salivary flow (empty column) and the $\mathrm{K}^{+}$-concentration of saliva (shaded column). Horizontal line of the potential record indicates the level of resting potential, while the hyperpolarized curve indicates the secretory potential. $\mathrm{K}^{+}$concentration in the perfusate being raised over $13 \mathrm{mM}$, the secretory potential was completely abolished, while the secretion of saliva remained, though its rate was reduced.

By raising the potassium concentration in the perfusate, by the addition of various amounts of isotonic $\mathrm{KCl}$ solution to the arterial blood to be perfused, the intracellular potential was influenced considerably.

When the $\mathrm{K}$ concentration in the perfusate was normal, i. e. $4 \mathrm{mM} / 1$, the resting potential was $-40 \mathrm{mV}$ and the secreting potential was $-54 \mathrm{mV}$, while they were decreased to $-35 \mathrm{mV}$ and $-37 \mathrm{mV}$ respectively, on an average, by raising the potassium concentration to $11 \mathrm{mM}$ (FIG. 2 and 5). When the potassium concentration was $13 \mathrm{mM}$, the resting potential was $-34 \mathrm{mV}$ on an average, while no secretory potential appeared by stimulation, i.e. the intracellular potential remained unchanged by stimulation. The more the potassium concentration of perfusate was raised the more the resting potential was decreased, and it was $-20 \mathrm{mV}$ at the potassium concentration of $96 \mathrm{mM}$. Even in such a case of high potassium perfusate, the secretion of saliva still remained, though its rate decreased, as is seen in FIG. 2. The hyperpolarization of the intracellular potential was, however, completely abolished at a higher concentration of potassium than $11 \mathrm{mM}$ in the perfusate. The resting potential, secretory potential and the secreting rate of saliva were able to be restored promptly by returning the potassium concentration to a normal value in the perfusate, even after it was raised to $43 \mathrm{mM}$. 
Time signal
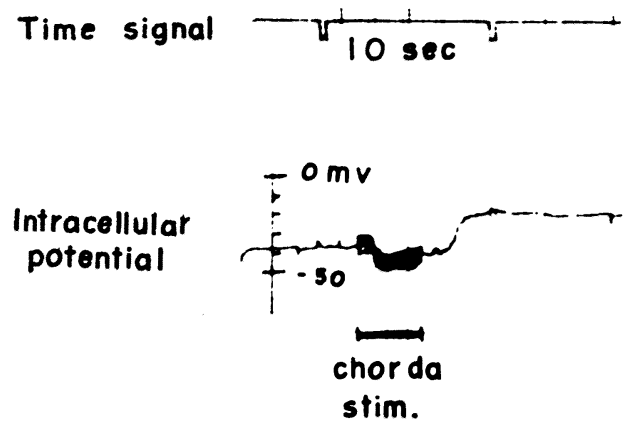

Fig. 3. A record of intracellular secretory potential of submaxillary gland of which $\mathrm{Cl}^{-}$in the perfusate was replaced completely with $\mathrm{SO}_{4}^{-}$ Ringer solution. The secretory po. tential remained almost normal 15 minutes after perfusion. The rest. ing potential of about $-40 \mathrm{mV}$ was hyperpolarized to $-50 \mathrm{mV}$ by chorda stimulation and a salivary secretion of $0.01 \mathrm{ml} / \mathrm{min} . / \mathrm{g} . g l a n d$ was obtained.

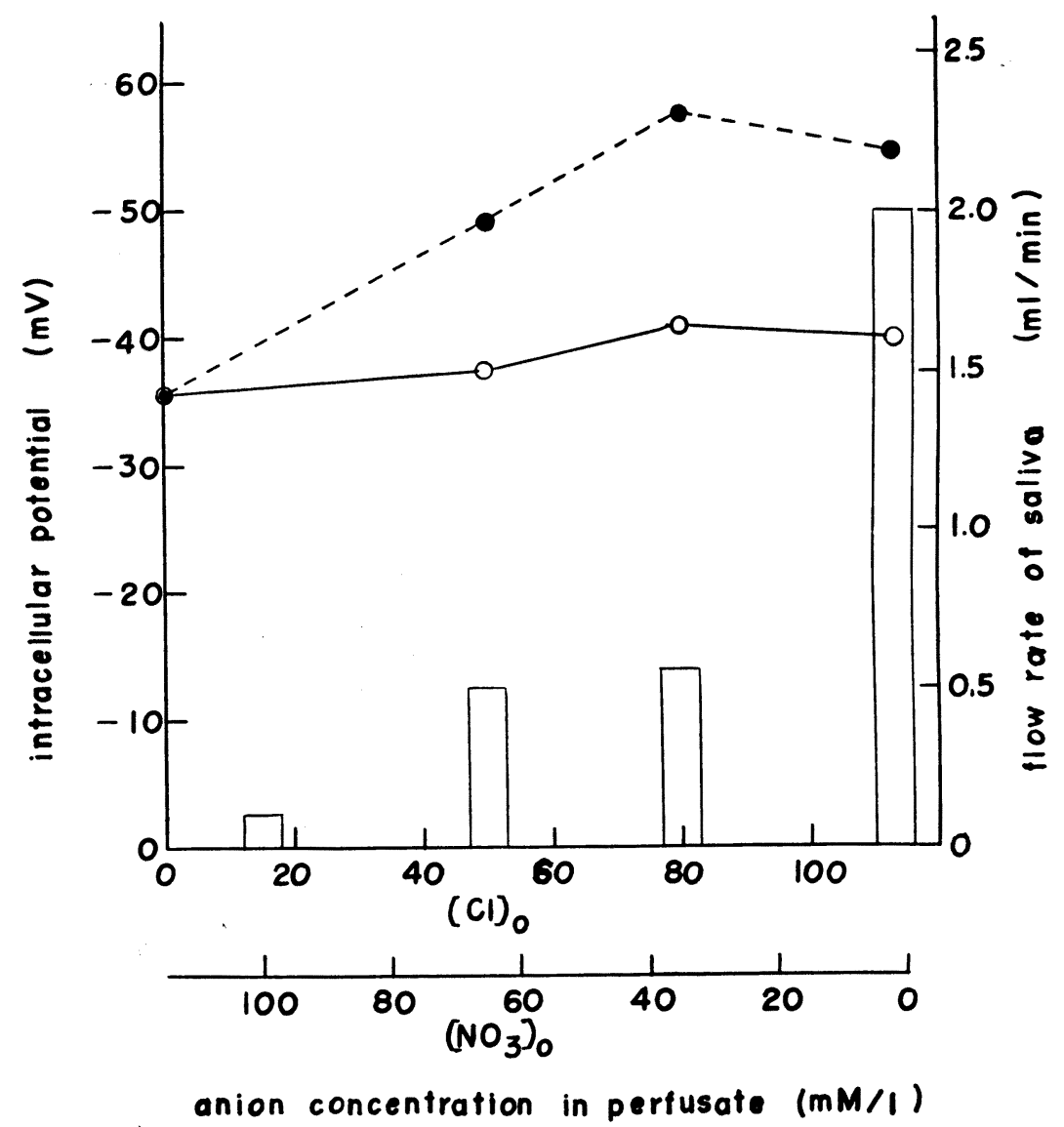

Fig. 4. Relationships between intracellular potential as well as flow rate of saliva and chloride concentration in the perfusate (replaced by nitrate). Open circles indicate the resting potential and solid circles the secreting potential. Columns show the maximum flow rate of saliva. 
When the gland was perfused with the potassium free solution, the normal secretory potential was still observed at $15 \mathrm{~min}$. after the start of perfusion, while the rate of salivary secretion was reduced markedly at 5-10 min., and disappeared at $15 \mathrm{~min}$. At that time, the resting and the secreting potential didn't differ so much from those of the control, while the secretory potential disappeared at $20 \mathrm{~min}$. As potassium was detected in $1 \mathrm{mM}$ or more in the perfusate from the vein, and the normal potassium concentration of dogs' red cells is not high, this $\mathrm{K}$ in the perfusate may be explained as mainly derived from the gland cell. By loosing potassium, probably the excitability of the gland cell was decreased as is generally observed with nerve and muscle cells, and thus the salivary secretion and secretory potential disappeared. By returning the potassium concentration of the perfusate to the normal value, the salivary secretion and the secretory potential were restored gradually and attained the normal state after about $20 \mathrm{~min}$.

On the other hand, the reduction of the sodium concentration to half of the normal plasma value by replacing part of the plasma with $\mathrm{Li}$-Ringer solution (see TABLE. 1) did not cause any appreciable change in the salivary secretion nor in the secretory potential even after $30 \mathrm{~min}$. while a complete replacement with $\mathrm{Li}$-ion abolished it promptly. Thus, the secretion and secretory potential are more sensitive to changes in the potassium than in the sodium in the perfusate. The complete replacement of chloride ion with sulphate ion could not affect the secretory potential until after $15 \mathrm{~min}$., while the salivary secretion was reduced appreciably (FIG. 3). The complete replacement of $\mathrm{Cl}^{-}$with $\mathrm{NO}_{3}^{-}$also abolished the salivary secretion and secretory potential immediately, while its half replacement did not affect them appreciably. In FIG. 4, the resting as well as secreting potential is plotted against the $\mathrm{Cl}$ concentration in the perfusate. The secreting potential seems to be affected somewhat by the replacement of $\mathrm{Cl}^{-}$with $\mathrm{NO}_{3}^{-}$. But the potential change is not so sensitive when compared with the influence of the $\mathrm{K}$ concentration on the secretion potential as is seen in FIG. 6. The secretion of saliva was reduced by a decrease of chloride concentartion in the perfusate. But its dependency on the chloride concentration does not coincide with the curve presented by LUNDBERG').

These results suggest that the chloride ion in the perfusate is not indispensable for the generation of hyperpolarization in the acinal cell membrane by electrical stimulation, and that the secretion does not necessarily accompany the secretory potential, while they are usually concomitant after stimulation.

Ionic balance study of gland tissue. Similar to the experiment by BURGEN ${ }^{1}$, the ionic balance of the gland was studied by measuring the ionic concentrations and the flowing rate of arterial, venous blood and of saliva by using the submaxillary gland of the dog.

The balance of all ions in the resting state was almost zero. The flowing 
rate of arterial and venous blood through the gland was about $0.2 \mathrm{ml} / \mathrm{min} . / \mathrm{g}$. gland, and the ionic concentration of the venous plasma was almost equal to that of the arterial plasma. The $\mathrm{K}$-concentration of the plasma was $4 \mathrm{mM} / 1$, $\mathrm{Na} 130 \mathrm{mM} / 1, \mathrm{Cl} 110 \mathrm{mM} / 1$ and inorganic $\mathrm{P}$ was $1.85 \mathrm{mM} / 1$.

When the chorda tympani was stimulated electrically, however, the ionic balance of the gland tissue was greatly affected. When the rate of salivary flow was about $0.2 \mathrm{ml} / \mathrm{min}$./g.gland, the $\mathrm{K}$-concentration of saliva was $30 \mathrm{mM} / 1$, $\mathrm{Na} 110 \mathrm{mM} / 1, \mathrm{Cl} 90 \mathrm{mM} / 1$ and inorganic $\mathrm{P} 0.6 \mathrm{mM} / 1$. The rate of blood flow

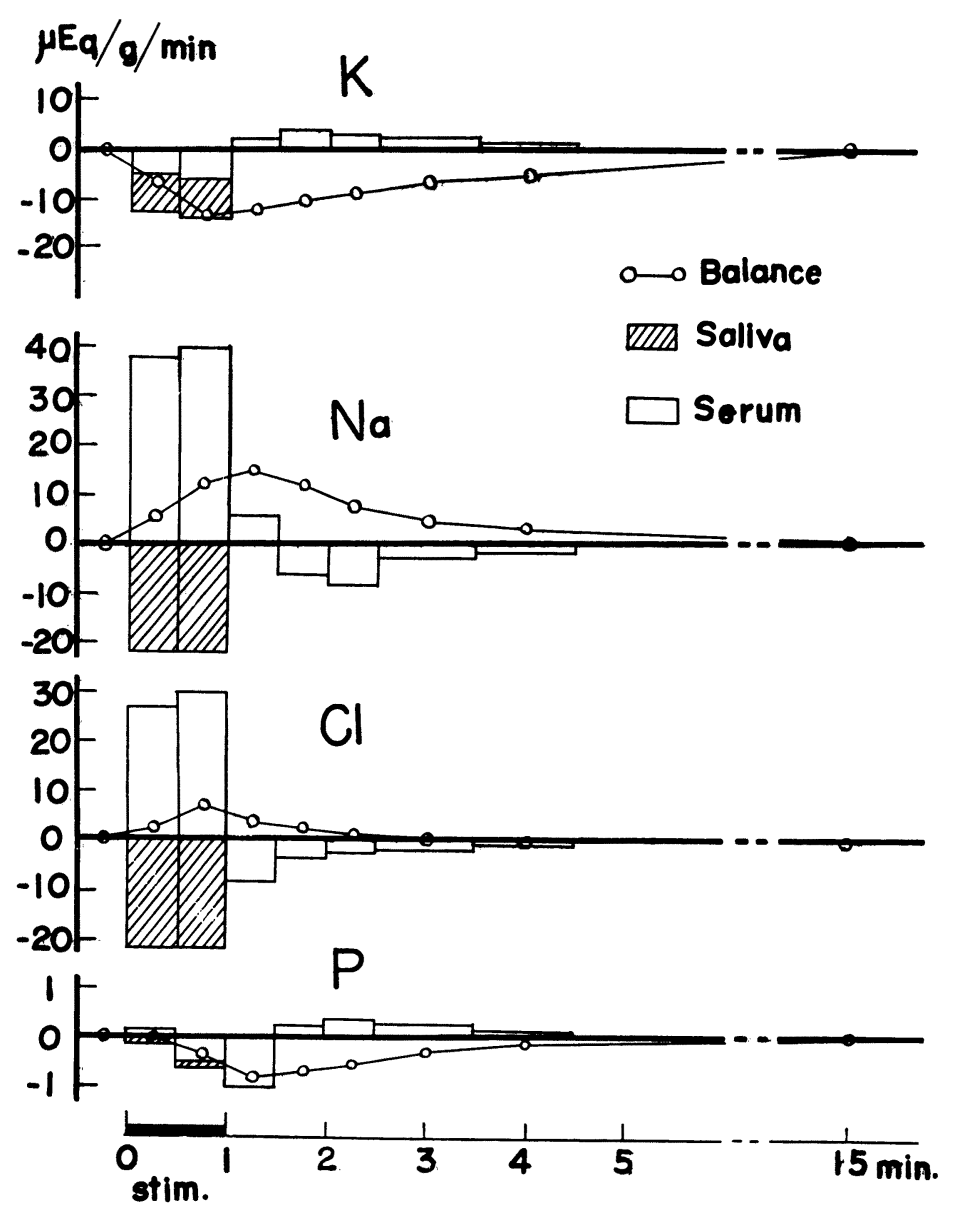

FIG. 5. Ionic movement of the gland tissue from or to serum and to saliva during and after chorda stimulation. Blank cloumn shows a gain (positive side) or a loss (negative side) of an ion in the gland tissue from or to serum at the rate of $\mu \mathrm{Eq} / \mathrm{g}$.gland/min. Shaded column shows that to saliva. Small circle along the curve shows the time course of the ionic balance in the gland tissue in $\mu \mathrm{Eq} / g$.gland. 
increased to $2.0 \mathrm{ml} / \mathrm{min}$./g.gland on a maximum, and the ionic concentration of the venous plasma changed greatly compared with that of the arterial plasma, e. g. $\mathrm{K}$ was $9.3, \mathrm{Na} 124, \mathrm{Cl} 110$ and inorganic $\mathrm{P} 4.5$ in $\mathrm{mM} / 1$.

The difference of the flowing rate between arterial and venous blood being assumed to equal the rate of salivary flow, the balance of the various kinds of ions in the gland tissue in the resting state as well as secreting state was. calculated as follows:

Let $\mathrm{Va}, \mathrm{Vv}$ and $\mathrm{Vs}$ represent the rate of arterial, and venous blood flow through the gland and the rate of salivary flow, respectively: then the ionic. balance of the gland tissue is given by the following equation,

(net loss or gain or an ion of gland tissue) $=\mathrm{Ca} \times \mathrm{Va}(1-\mathrm{Ha})-\mathrm{Cv} \times \mathrm{Vv}(1-\mathrm{Hv}$ ) and,

(the rate of loss of that in saliva $)=-\mathrm{Vs} \times \mathrm{Cs}$

where $\mathrm{Ca}, \mathrm{Cv}, \mathrm{Cs}$ are the ionic concentration of the arterial and venous plasma, and saliva, respectively, $\mathrm{Ha}$ and $\mathrm{Hv}$ are the hematocrits of the arterial and venous blood, respectively.

FIG. 5 represents the balances of ions of the gland tissue in the resting. state, the secreting state and the state of restoration after secretion. The histogram which stands on the horizontal base line (positive side) represents. the input of ions into the gland tissue, while that under the base line (negative side) is the output, and the balance between the two is indicated by a small circle along the curve of balance which represents the time course of the ionic balance in the gland tissue. By algebraically summing up the positive and. negative gain of ions in the gland tissue during the stimulation and also during: the period of restoration, the ionic balance in the tissue is obtained as indicated by the following table:

TABLE 2. Gain ( + ) or loss (-) of ions of gland in $\mu \mathrm{Eq} / \mathrm{g}$. gland.

a) during stimulation for $1 \mathrm{~min}$.

\begin{tabular}{c|c|c|c|c}
\hline ion & blood & saliva & balance & sum \\
\hline $\mathrm{K}^{+}$ & -6.0 & -7.8 & -13.8 & -2.3 \\
\hline $\mathrm{Na}^{+}$ & +39.0 & -27.5 & +11.5 & +6.5 \\
\hline $\mathrm{Cl}^{-}$ & +28.5 & -22.5 & +6.5 & +6 \\
\hline
\end{tabular}

b) for $15 \mathrm{~min}$. after stimulation.

\begin{tabular}{|c|c|c|c|c|}
\hline ion & blood & saliva & balance & sum \\
\hline $\mathrm{K}^{+}$ & +13.7 & - & +13.7 & \multirow{2}{*}{+2.7} \\
\hline $\mathrm{Na}^{+}$ & -11.0 & - & -11.0 & \\
\hline $\mathrm{Cl}^{-}$ & -7.5 & - & -7.5 & -7.5 \\
\hline
\end{tabular}


It is shown in FIG. 5 that the potassium was transferred the gland tissue into the blood as well as saliva during the secreting state. This fact is described as "potassium transient" by BURGEN"). After the cessation of stimulation, i. e. during the state of restoration, the potassium was taken into the gland tissue from the blood, and the zero balance of potassium was attained 15 minutes after the end of stimulation. As is seen in the table the total balance of $\mathrm{K}$ in the gland during stimulation for 1 minute is $-13.8 \mu \mathrm{Eq} / \mathrm{g}$, while it is $+13.7 \mu \mathrm{Eq} / \mathrm{g}$ during the restoration period after 15 minutes. Thus, the restoration is completed in 15 minutes. Concerning the sodium and chloride, a large amount of respective ion was taken from the blood and was transferred into the saliva during the secreting state. And some of it was, however, retained somewhat in the gland, while it was driven out to the blood during the restoring state. The zero balance of sodium as well as chloride was achieved almost completely after 15 minutes in the restoring state, as is indicated in the table.

The balance of inorganic phosphate in the gland presented a similar loss to that described above. These movements of ions seem to be coupled with the metabolic processes in the gland. The movement of sodium and chloride seems to be caused by the mechanism of salivary secretion, while the potassium transient may be caused by the increase of potassium permeability of the gland cell membrane in the secreting state.

Ionic concentration of the gland. In attempt to reconfirm the results obtained in the balance study of the gland, the ionic concentration of the gland tissue was analysed in the resting as well as the secreting state. Five dogs were used for the experiment. $\mathrm{Na}^{+}$contained in the resting submaxillary gland of the dog was $34 \pm 2.8 \mathrm{mM} / \mathrm{Kg}, \mathrm{K}^{+} 65.4+1.7 \mathrm{mM} / \mathrm{Kg}$ and $\mathrm{Cl}^{-} 60.8+3.6 \mathrm{mM} / \mathrm{Kg}$ tissue weight. The water content of the resting gland was $78.1 \pm 1.4 \%$, and the inulin space was $23 \%$ of tissue weight. As the concentration in plasma water was $145 \mathrm{mM}$ for $\mathrm{Na}^{+}, 4$ for $\mathrm{K}^{+}$and $114 \mathrm{for}^{-}$, the following intracellular con centration was obtained: $\mathrm{Na}^{+} 3, \mathrm{~K}^{+} 117$ and $\mathrm{Cl}^{-} 62 \mathrm{mM} / \mathrm{Kg} \mathrm{H}_{2} \mathrm{O}$. In this experiment, care was taken not to stimulate the chorda tympani prior to excising the gland. The ionic content of the secreting submaxillary gland of the dog was measured with a gland which was excised after 5 minutes stimulation of the chorda tympani with the current of $2 \mathrm{~V}, 20 \mathrm{cps}$. The contents of the ions in the gland tissue were as follows, $\mathrm{Na}^{+} 51.6 \pm 4.5, \mathrm{~K}^{+} 48.0 \pm 8.7$ and $\mathrm{Cl}^{-} 58.6 \pm 4.5 \mathrm{mM} / \mathrm{Kg}$ tissue weight. As the water content of the gland was $76.8 \pm 0.2 \%$, and the inulin space was $23 \%$, the following average intracellular concentration was obtained: $\mathrm{Na}^{+} 34, \mathrm{~K}^{+} 89$ and $\mathrm{Cl}^{-} 60 \mathrm{mM} / \mathrm{Kg} \mathrm{H} \mathrm{H}_{2} \mathrm{O}$. Thus, the gland gained $31 \mu \mathrm{Eq} / \mathrm{g}$ cell water of $\mathrm{Na}^{+}$, while it lost $28 \mu \mathrm{Eq} / \mathrm{g}$ cell water of $\mathrm{K}^{+}$during the $5 \mathrm{~min}$. stimulation.

These results almost coincide with that of the ionic balance study, indicating that the gland tissue gained $11.5 \mu \mathrm{Eq} / \mathrm{g}$ tissue of $\mathrm{Na}^{+}$, while it lost 13.8 
$\mu \mathrm{Eq} / \mathrm{g}$. gland of $\mathrm{K}^{+}$during the 1 minute stimulation. The fact that $6.5 \mu \mathrm{Eq} / \mathrm{g}$. gland of $\mathrm{Cl}^{-}$is gained in the balance study during the 1 minute stimulation, while the balance was almost zero in the gland cell for the 5 minutes stimulation, may be explained by the fact that the tissue fluid was retained in the gland tissue during stimulation.

\section{DISCUSSION}

According to LUNDBERG, the hyperpolarization potential of the acinal cell ${ }^{6-10)}$ during the stimulation, i. e. the secretory potential originates the active transport of $\mathrm{Cl}^{-}$ion and initiates the secretion of salt and water through the acinus cell. In the present authors' study, however, it was verified by the perfusion experiments that the salivary secretion is not always concomitant

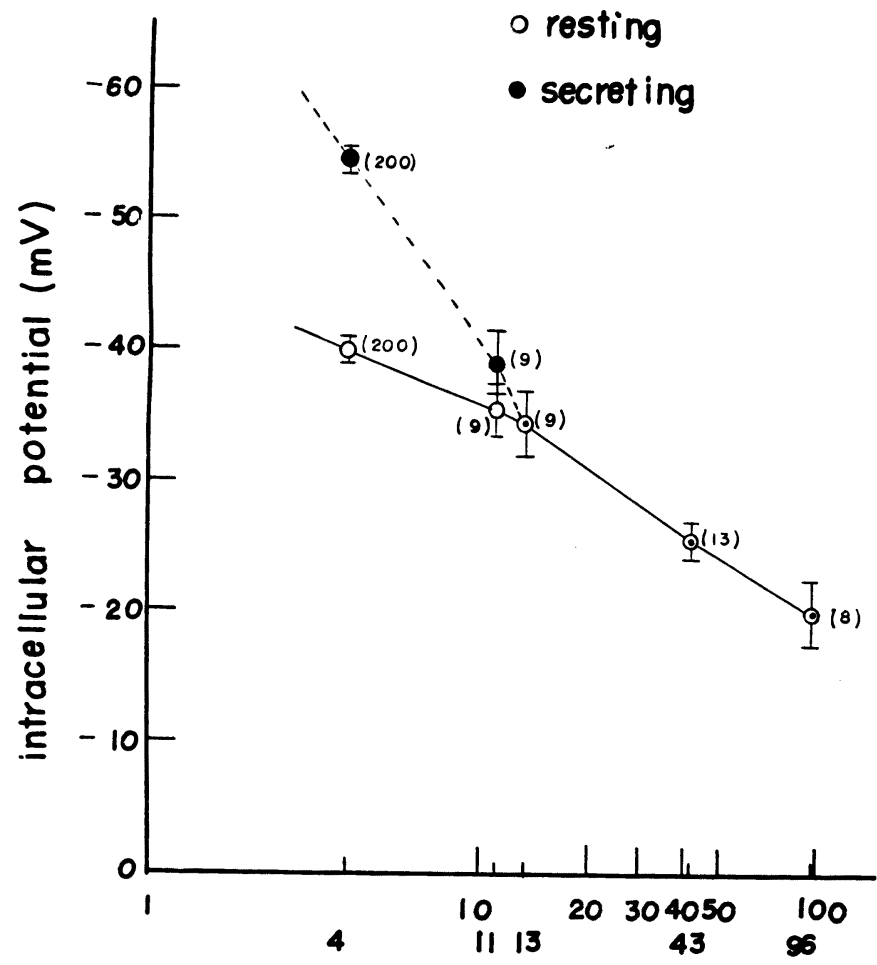

\section{potassium concentration in perfusate $(\mathrm{mM} / \mathrm{I})$}

FIG. 6. Relationship between intracellular potential and potassium concentration in perfusate. Open circles indicate the resting state, and solid circles the secreting state. The height of the vertical line denotes the standard error of the mean, and the figures in parenthesis indicate the number of observation. 
with the secretory potential, and the secretion can be detected when the hyperpolarization is abolished by an increased $\mathrm{K}^{+}$concentration in the perfusate, while it remains almost normal in the perfusion experiment with $\mathrm{SO}_{4}^{-}$-Ringer, when the secretion decreases appreciably. On the other hand it was indicated that the intracellular potential, as well as the secretory potential, was very sensitive to change in the potassium concentration of the perfusate (see FIG. 6). From the experiment of the ionic balance in the gland tissue, it was suggested that the permeability of the cell membrane for potassium increased during the secreting state, and the secretory potential may be explained as due to the equilibrium potential of potassium during the excited state of acinus cells. By adopting the Goldmans constant field hypothesis of the equilibrium potential, the membrane potential of the acinus cell, $E$, may be expressed as follows:

$$
E=\frac{R T}{F} \ln \frac{(K) o+q(N a) o+r(C l) i}{(K) i+q(N a) i+r(C l) o}
$$

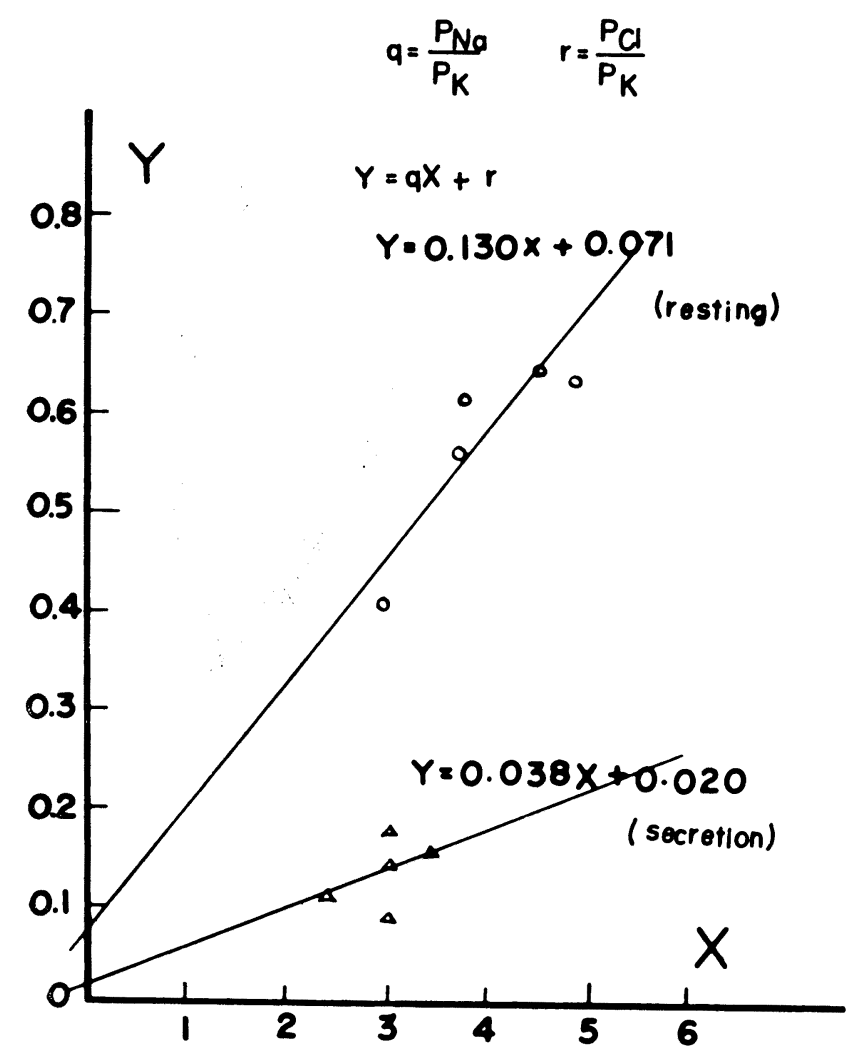

FIG. 7. Graphical calculation of $\mathrm{P}_{\mathrm{Na}} / \mathrm{P}_{\mathrm{K}}$ and $\mathrm{P}_{\mathrm{Cl}} / \mathrm{P}_{\mathrm{K}}$ in the resting state as well as the secreting state. Small circles show the resting state, and triangles show the secreting state. 
where $q=P_{N a} / P_{K}$ and $r=P_{C l} / P_{K}$, and $P$ is the permeability coefficient of the respective ion, and suffixes $O$ and $i$ mean "outside the cell and its inside", respectively. This equilibrium equation was applied to the intracellular potential of the submaxillary gland at various states, i. e. the gland perfused with Ringer of which the potassium content was changed from 4 to $13 \mathrm{mM} / \mathrm{l}$. The above equation can be converted into the following general form $Y=q x+r$, where, $\mathrm{Y}$ and $\mathrm{X}$ can be determined by the above-mentioned experiments with perfusates of different ionic compositions. By means of the method of least square, the parameters $q$ and $r$ were determined as follows (see FIG. 7).

At the resting state, $q=0.130 ; r=0.071$

At the secreting state, $q=0.038 ; r=0.020$

These data suggest that the rate of increase of potassium permeability to that of $\mathrm{Na}^{+}$and $\mathrm{Cl}^{-}$at the secreting state is about 3.5 times at high as those at the resting state. Thus, it is deduced that the secretory potential may be explained as being due to an increase of $\mathrm{K}^{+}$permeability of the cell membrane by which the potential approaches the $\mathrm{K}^{+}$equilibrium potential.

When the gland was perfused with the potassium free solution to reduce its intracellular concentration, the secretion of the gland disappeared rapidly, while the secretory potential remained until about 20 minutes after the commencement of perfusion. When the gland was perfused with a high potassium solution, the secretion was decreased, but it remained even with a solution of $96 \mathrm{mM} \mathrm{K}$, when the concentration in the saliva was raised, while the secretory potential disappeared even with the perfusate of $13 \mathrm{mM} \mathrm{K}$. Thus, it is inferred that the secretion of saliva is more sensitive to a loss of intracellular potassium than the secretory potential is, while the salivary secretion is more resistant to the increase of potassium concentration of the perfusate than the secretory potential which is initiated by an increase of potassium permeability of the cell membrane during stimulation.

In any case, the secretory potential is by no means the cause of salivary secretion, while the initiation of the two are sometimes concomitant. As was demonstrated by the electron micrographys of FUJITA et al..2), the pinocytosis and the basal infoldings along the outer cell membrane of acinus cell increased during the secretion. Thus, the cell drinking mechanism is suggested as being the factor that initiates the salivary secretion. On the other hand, the initiation of the secretory potential seems to be explained by an increased permeability of the cell membrane to potassium ion which makes the intracellular potential approach the equilibrium potential of potassium.

In this connection, it should be mentioned that LUNDBERG experimented with cat's sublingual gland, while the present experiments were performed with dog's submaxillary gland. As the ionic composition of saliva from cat's sublingual gland (mainly composed of $\mathrm{Na}, \mathrm{K}, \mathrm{Cl}$ is quite different from that of submaxillary saliva of the dog, the above discussion on salivary secretion 
may not be applicable to cat's sublingual gland. In the case of dog's submaxillary gland, however, the ionic composition $\left(\mathrm{Na}, \mathrm{K}, \mathrm{Cl}, \mathrm{HCO}_{3}\right)$ of precursor saliva taken from the terminal portion of the gland is close to that of serum, as was reported by ToYOKI ${ }^{14)}$. Therefore the secretion of ions in the terminal portion of gland cannot be explained under the posturation of Cl-pump. If the active transport of individual ions in saliva were to appear in its secretion, many pumps of various ions which act to transport ions so as to produce a tissue fluid like excreta should be postulated. Posturation of such a complicated pump of active transport seems rather ridiculous. Thus, the cell drinking through the acinus cell seems to be the most possible mechanism of secretion of the precursor saliva.

\section{SUMMARY}

The perfusion experiments were performed with dog's submaxillary gland and the mechanism of salivary secretion and the initiation of the secretory potential were studied by means of the microelectrode technique. Results obtained are as follows:

1. The intracellular potentials were very sensitive to changes of $\mathrm{K}^{+}$concentration in the perfusate. When $\mathrm{K}^{+}$was raised over $13 \mathrm{mM} / \mathrm{l}$, the secretory potential completely disappeared, while the secretion was still observed. Even when $\mathrm{Cl}^{-}$in the perfusate was replaced completely by sulphate, the secretory potential remained pratically normal 15 minutes after starting the perfusion, but the rate of salivary flow decreased.

Therefore, the secretory potential is not the causal factor of secretion, and it seems to originate from some other factor than the $\mathrm{Cl}^{-}$pump along the cell membrane of the gland acinus.

2. From the balance study, it was concluded that the gland lost $\mathrm{K}^{+}$with the rate of about $14 \mu \mathrm{Eq} / \mathrm{g}$.gland $/ \mathrm{min}$. into the blood and saliva during the secretion, while it was restored into the gland from the blood after cessation of stimulation and the restoration was completed in $15 \mathrm{~min}$., $\mathrm{Na}^{+}$and $\mathrm{Cl}^{-}$were retained in the gland tissue en route from the blood to saliva by stimulation, while they were completely driven out and then into the blood during the restoration of $15 \mathrm{~min}$. By analysis of the ionic concentration in the gland tissue, a similar ionic movement was observed. The $\mathrm{K}^{+}$in the gland decreased during the salivary secretion, whereas the $\mathrm{Na}^{+}$concentration increased.

3. It is clarified by the aid of GoldmAN's equation that the rate of potassium permeability to that of the other ions increased more markedly in the secreting state than in the resting state. Thus, the equilibrium potential which is manifested by the increase of $\mathrm{K}$ permeability during the stimulation of the gland seems to account for the hyperpolarization of the intracellular potential of the gland acinus. The secretion of saliva is not necessarily concomitant 
with the hyperpolarization of the cell membrane potential, and should be explained by some other factor than the secretory potential. A possible mechanism of salivary secretion was suggested in the discussion.

\section{REFERENCES}

1) Burgen, A.S. V. The Secretion of potassium in saliva. J. Physiol., 132:20-39, 1956.

2) Fujita, H., Macino, M., Nakagami, K., Imai, Y. and Yamamoto, Y. Electron microscopic studies on the submandibular glands of normal and parasymathicus stimulated dogs (Japanese). Acta Anatomica Nipponica 39: 269-293, 1964.

3) INole, T. Studies on excretory mechanism of saliva with perfused salivary gland (part I, II, and III) (Japanese). J. Physiol., Soc. Jap., $20: 430-443,444-452,734-743$. 1958.

4) ImaI, Y. Studies on the secretory mechanism of submaxillary gland of dog (part 1 and 2) (Japanese). J. Physiol. Soc. Jap., $27:$ 304-312, 313-324, 1965.

5) ImaI, Y. AND Yamamoto, Y. Studies of salivary secretion of the submaxillary gland of dog. Abstracts of papers of XXIII International Congress of Physiological Sciences. No. 125 , p. 77,1965 . Tokyo Japan.

6) Lundierg, A. The electrophysiology of submaxillary gland of the cat. Acta Physiol. Scand., 35: 1-25, 1955.

7) Lundierg, A. Secretory potential in the sublingual gland of the cat. Acta Physiol. Scand., $40: 21-34,1957$.

8) LundBerg, A. The mechanism of establishment of secretory potential in sublingual gland cells. Acta Physiol. Scand., $40: 35-58,1957$.

9) Lundierg, A. Anionic dependence of secretion and secretory potential in the perfused sublingual gland. Acta Physiol. Scand., 40: 101-112, 1957.

10) Lundberg, A. Electrophysiology of salivary gland. Physiological Review 38:2140, 1958.

11) Schneyer, L. H., And Schneyer, C. A. Electrolyte and inulin spaces of rat salivary glands and pancreas. Am. J. Physiol. 199: 649-652, 1960.

12) Schneyer, L. H. And Schneyer, C. A. Electrolyte and water transport by salivary gland slices.

13) Schneyer, L.H, And Schneyer, C. A. Influence of pilocarpine on transport by salivary gland slices. Am. J. Physiol., 205 : 1058-1062, 1963.

14) TочокI, M. Role of striated part in salivary gland on ionic excretion (Japanese). J. Physiol. Soc. Jap., 24, 553-568, 1962.

15) Yoshimura, H., Inoue, T., Fujimoto, T. And Matumoto, S. Improvements in the perfusion method of salivary gland of dog (Japanese). J. Physiol. Soc. Jap., 24, 111-117, 1962. 